\title{
The Divine Response to Violence in Genesis 4:1-16: A Model for Nigerian Christians' Response to Terrorism
}

\author{
Babatunde Adekunle Ogunlana (PhD) \\ Baptist Theological Seminary, P.O. Box 94, Kaduna, Nigeria
}

\begin{abstract}
Terrorism is a global phenomenon. It occurs virtually in all parts of the world, Nigeria inclusive. It is one of the various forms of violence against Christians in Nigeria. It usually comes in the form of extremists' attacks against Christians in Nigeria. With the high prevalence of such attacks against Christians, what should be the Christian response to them? I adopt a descriptive approach to argue that prayer is an effective way of responding to violence against Christians in Nigeria. In order to achieve this purpose, I first engage in exegeting Genesis 4:1-16. Afterward, I describe the nature of violence against Christians in Nigeria. Finally, I describe what should be the response of Christians in Nigeria to violence against them.
\end{abstract}

Keywords: Christians in Nigeria, Violence, Divine Response, Terrorism, Nigerian Christians' Response DOI: $10.7176 / \mathrm{JPCR} / 43-01$

Publication date: April $30^{\text {th }} 2019$

\section{Introduction}

Terrorism is a global phenomenon. It occurs virtually in all parts of the world. It has become one of the leading causes of death in the world. It is one of the various forms of violence. It usually comes in the form of extremists' attacks against Christians in Nigeria. With the high prevalence of such attacks against Christians, what should be the Christian response to them? I think Christians should learn from how God responded to the first violence as recorded in Genesis 4. Thus, this article examines the divine response to violence with the focus on Genesis 4. Genesis 4 is concerned with how God responded to the first blood shed by the first perpetrator of violence. In the article, I argue that prayer is an effective way of responding to violence against Christians. I adopt a descriptive approach in the article.

\section{Historical and Literary Background of Genesis 4}

Genesis 4 belongs to the division called primeval history. This division highlights different origins: the origins of earth's creation, of humankind, of the institution of marriage, of sin, of judgment, of the covenant and the like. As for Genesis 4, it is concerned with the origins of childbirth, sacrifice, violence, shedding of human blood and God's response to such offense, civilization, and worship through prayer.

Genesis 4 belongs to J-source. The author is regarded as the master of narrative style. He was responsible for the composition of Genesis 2-4. This is because Genesis 4 is closely connected with Genesis 2-3. According to Collins, the same expression is found in these chapters. For instances, עבד אדמה, 'to work the ground' occurs in only Genesis $2-4(2: 5,15,3: 23 ; 4: 2,12) .{ }^{1}$ The phrase 'but you rule over it' in $4: 7$ is paralleled to the last phrase of 3:16 ('and he shall rule over you') and both verses use that rare word תשוקה, 'desire'. Cain says that God has driven him away in $4: 14$, echoing the same verb that in 3:14, 'he drove out the man'. Finally, the only biblical references to 'east of Eden' are in 3:24 and 4:16. Genesis 3 ended with Adam and Eve being sent out of Eden because of their disobedience. In Genesis 4, we see the result of that disobedience as it spreads through their offspring. $^{2}$

The genre of Genesis 4 is standard narrative prose as was the case with Genesis 2-3. It describes what happened to the first family after their disobedience in Eden. It illustrates both the decline into sin that resists from the first disobedience and the enduring faithfulness that God has to his promise. ${ }^{3}$ It shows how the family began life outside the garden, and how sin, began to run its course among humankind. ${ }^{4}$

In Genesis 4, there are three episodes: 1-16; 17-24; 25-26. According to Collins, the first episode (Genesis 4:1-16) has its peak at Genesis 4:10-12 where Yahweh pronounces judgment on Cain in terms that are similar to Genesis 3:14, 17 which occurs in the peak of its periscope. The second episode (Genesis 4:17-24) focuses on Cain's offspring. It consists of a genealogy, which mentioned Cain and his descendants fathering successive sons until we come to Lamech. God is notably absent from these verses, except by allusion to his promise of vengeance for Cain (Gen 4:24 cf. Gen 4:15). This episode has its peak at Genesis 4:23-24, the boastful song of Lamech. Here he addresses the other participants of this subunit, Adah, and Zillah, and the speech is in high style exhibiting parallelism. The third episode (Gen 4:25-26) focuses on Seth. In this episode, Adam, Eve and Seth are

\footnotetext{
${ }^{1}$ C. John Collins, Genesis 1-4: A Linguistic, Literary, and Theological Commentary (Phillipsburg: P\&R Publishing, 2006$), 189$.

${ }^{2}$ Collins, 190.

${ }^{3}$ Collins, 189.

${ }^{4}$ Collins, 245 .
} 
the actors. The periscope ends with the vague 'people began'. Eve's speech in Genesis 4:25 is likely the peak of this episode. ${ }^{1}$

\section{Exegetical Notes}

In this section, the focus of the exegetical notes will be in Genesis 4:1-16. The text mentions five participants: Yahweh, Adam, Eve, Cain and Abel. In most of the verses, only two actors are in view (Adam and Eve, Abel and Cain, or Cain and Yahweh). There are two conversations between Cain and Yahweh, who take the initiative in both verses 6-7 and the longest subunit, 9-15.

\subsection{Genesis 4:1-2 - The Births and Occupations of Cain and Abel}

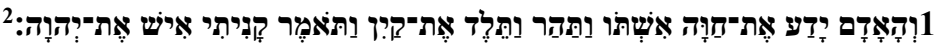

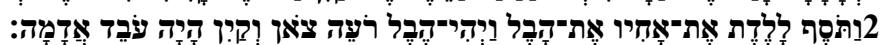

1 Now Adam knew Eve his wife, and she conceived and bore Cain, saying, "I have gotten a man with the help of the LORD." 3

2 And again, she bore his brother Abel. Now Abel was a keeper of sheep, and Cain a worker of the ground.

The focus of Genesis 4:1-2 is on the births and occupations of Cain and Abel. After Adam and Eve were driven out of the Eden, the event in verse one took place. The first thing highlighted is that Adam knew his wife, Eve. The Hebrew word Eve's pregnancy that led to Cain's birth. Eve exclaims, 'I have acquired a man from Yahweh'. The verb קָנִיתחית used in this exclamation sound much like קיק, 'Cain'. ${ }^{4}$ The verb can also have the sense of 'to get, or to own'. By implication, Eve has created or owned איפי 'a man-child' with the help of God. ${ }^{5}$ She later gave birth to his brother Abel, whose Hebrew word דָָּ means 'the greatest vanity', 'vapor', or 'nothing less'.6 Cain carries on his father's vocation; he is a tiller of the soil. Abel is a keeper of flocks, a shepherd. Thus, two different individuals with two different occupations were born by Adam and Eve.

\subsection{Genesis 4:3-5 - The Offering of Sacrifices}

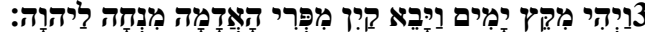

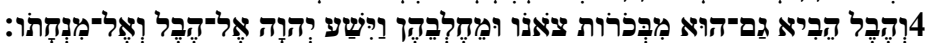

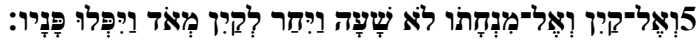

3 In the course of time, Cain brought to the LORD an offering of the fruit of the ground,

4 and Abel also brought of the firstborn of his flock and of their fat portions. And the LORD had regard for Abel and his offering,

5 but for Cain and his offering he had no regard. So Cain was very angry, and his face fell.

The focus of Genesis 4:3-5 is on the two sacrifices offered by Cain and Abel. In these verses is the first act of worship through sacrifices. Cain and Abel brought their offering to Yahweh. By implication, they have erected altars and placed the offering on or before it. ${ }^{7}$ Each brought מִנִח, 'an offering', appropriate to his occupation. ${ }^{8}$ Their offerings are meant to pave way for the sacrificial system of Leviticus. Cain's is a type of grain offering and Abel's is a type of peace offering. ${ }^{9}$

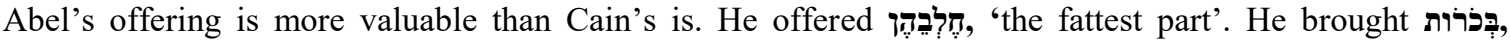
'firstlings' of his flock. However, Cain presented neither fruits that are the best nor the first fruit. Yet the text does not indict Cain for not presenting the first fruit. ${ }^{10}$ Consequently, Abel's offering was accepted by Yahweh and Cain rejected. According to Rad, Abel's sacrifice is meant to honor God, and God, in return, showed regard for his sacrifice. ${ }^{11}$ As a result, hot resentment rose in Cain, and Abel was persecuted for this. ${ }^{12}$

\subsection{Genesis 4:6-7 - The First Conversation of God with Cain}

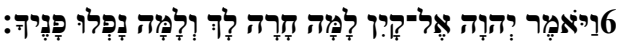

\footnotetext{
${ }^{1}$ Collins, 208-209.

${ }^{2}$ The Hebrew Text is taken from BHS.

${ }^{3}$ The English Text is taken for ESV

${ }^{4}$ Victor P. Hamilton, The Book of Genesis Chapters 1-17, (The International Commentary on the Old Testament) (Grand Rapids: Eerdmans, 1990), 220.

${ }^{5}$ Collins, Genesis 1-4: A Linguistic, Literary, and Theological Commentary., 195.

${ }^{6}$ Hamilton, The Book of Genesis Chapters 1-17, 222.

${ }^{7}$ Hamilton, 222.

${ }^{8}$ Hamilton, 223.

${ }^{9}$ Collins, Genesis 1-4: A Linguistic, Literary, and Theological Commentary., 215.

${ }^{10}$ Hamilton, The Book of Genesis Chapters 1-17, 223.

${ }^{11}$ Gerhard von Rad, Genesis: A Commentary, (The Old Testament Library) (Philadelphia: The Westminster Press, 1972$), 104$.

${ }^{12} \operatorname{Rad}, 104$.
} 
6 The LORD said to Cain, "Why are you angry, and why has your face fallen?

7 If you do well, will you not be accepted? And if you do not do well, sin is crouching at the door. Its desire is for you, but you must rule over it."

Genesis 4:6-7 records the first God's conversation with Cain. God cautioned Cain by asking him 'why he was angry, and his face downcast'. In verse 7, God continued to speak to Cain by telling him that if you do well, will there not be a lifting up. Rad comments that God warns Cain about the change of his being and the anger of his sin. He describes sin as being lying in wait that is, he compares sin with a beast of prey lying before the door. Sin shows it as an objective power which is outside the man and over him, wanting eagerly to take possession of him. Thus, Cain must master it and curb it. ${ }^{1}$

\subsection{Genesis 4:8 - The First Violence}

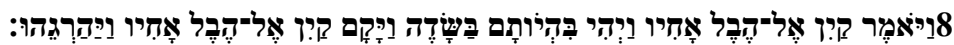

8 Cain spoke to Abel his brother. And when they were in the field, Cain rose up against his brother Abel and killed him.

Genesis 4:8 narrates Cain's violent action against his brother. Cain lured Abel to the field by saying 'let us go out to the field'. This statement is omitted in the Masoretic text but is found in the Septuagint. Cain killed

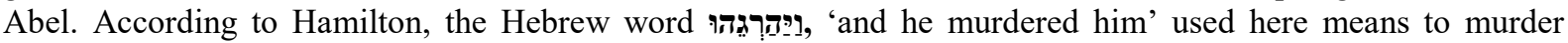
intentionally and is to be distinguished from רצי , 'to kill' which is used in the sixth commandment (Exodus 20:13). This then demonstrates that Cain could not restrain his resentment and bitterness. He vented his wrath on Abel. Hamilton further explains that Abel was killed because of God due to an unchecked envy and jealous on Cain's part. Rather than accept God's decision, he rejects the one God has accepted. He has eliminated Abel, what will he do with God? ${ }^{2}$

\subsection{Genesis 4:9-15 - The Second Conversation of God with Cain}

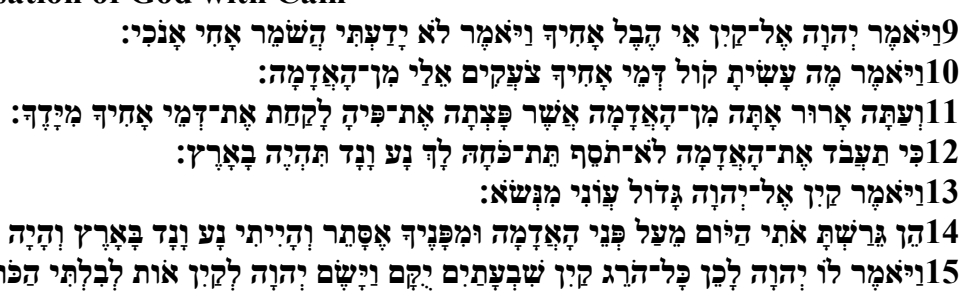

9 Then the LORD said to Cain, "Where is Abel your brother?" He said, "I do not know; am I my brother's keeper?"

10 And the LORD said, "What have you done? The voice of your brother's blood is crying to me from the ground.

11 And now you are cursed from the ground, which has opened its mouth to receive your brother's blood from your hand.

12 When you work the ground, it shall no longer yield to you its strength. You shall be a fugitive and a wanderer on the earth."

13 Cain said to the LORD, "My punishment is greater than I can bear.

14 Behold, you have driven me today away from the ground, and from your face, I shall be hidden. I shall be a fugitive and a wanderer on the earth, and whoever finds me will kill me."

$\mathbf{1 5}$ Then the LORD said to him, "Not so! If anyone kills Cain, vengeance shall be taken on him sevenfold." And the LORD put a mark on Cain, lest any who found him should attack him.

The focus of Genesis 4:9-15 is on God's second conversation with Cain after he had murdered Abel. Following the crime, comes the divine investigation as in Genesis $3 .{ }^{3}$ God asked Cain, where is Abel, your brother? Then Cain replied to God, 'I do not know, am I my brother's keeper'. Thus, God's question to Cain is inappropriate. Afterward, God prosecuted Cain. This is because Abel's blood cries from the ground and is heard by God.

Hamilton describes the Hebrew word צעיפקים, 'is crying' as the cry of the oppressed, the afflicted, the stranger, the weak, and the helpless. The word is usually associated with the groans of an innocent victim who is

\footnotetext{
${ }^{1} \operatorname{Rad}, 105$.

${ }^{2}$ Hamilton, The Book of Genesis Chapters 1-17, 230.

${ }^{3}$ Hamilton, 230.
} 
violated. ${ }^{1}$ Rad says that Abel's blood had raised a cry of complaint; his cry has come directly before God's throne. ${ }^{2}$ Furthermore, Hamilton comments that the blood of Abel itself does not endanger Cain. The shed blood simply cries out to God and leaves the matter with him. Presumably, it is for vindication that Abel's blood cries out. For Cain, is now blood guilty, he is liable to punishment for shedding blood. ${ }^{3}$

God punished Cain. God banished him from the soil. By implication, God refuses to kill him. Rather, the earth is to deny him its power of blessing. ${ }^{4}$ In addition, there will be no home for him because God has

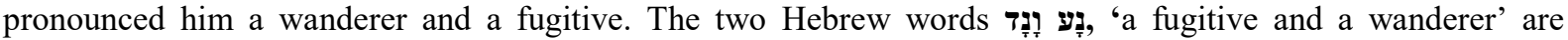
hendiadys meaning a wandering fugitive. According to Hamilton, the two Hebrew words indicate the aimlessness of the movement, which is worse than death. ${ }^{5}$ Thus, he has lost God's protection, and God has withdrawn his hand from him. God then placed his mark on his body. ${ }^{6}$

Cain then complains about the grievousness of his punishment. In his opinions, the judgment is too harsh. Hamilton re-interprets the punishment as follows: first, there will be only a meager return from the soil; second, he will be hidden from God's face; third, he is forced into a life of nomadism; lastly, he will be open game for anybody who meets him. ${ }^{7}$ Cain complained about the punishment because he was afraid to be killed. God then says whoever kills Cain will be avenged sevenfold. The Hebrew verb ?י? 'vengeance will be taken' is used in connection with the blood vengeance. God put a mark on Cain. According to Hamilton, the mark can be a sign of proof or evidence of God's power, a sign of cognition awakening knowledge of something in the observer, a sign that identifies Cain as one who is specially protected by God. ${ }^{8}$

\subsection{Genesis 4:16 - The Reality of Cain's Punishment}

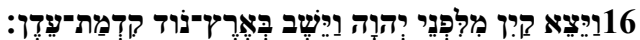

16 Then Cain went away from the presence of the LORD and settled in the land of Nod, east of Eden.

Genesis 4:16 emphasizes Cain's departure from the presence of God. Cain left God's presence and settled in Nod, which is a symbolic place name for Cain's new home beyond Eden. ${ }^{9}$

\section{Theological Implication}

\subsection{Description of Violence and Terrorism}

Violence is an aftermath of the sin of Adam. It was originated in the earth where Adam and the woman were driven. Cain was the first perpetrator of violence, and Abel the first victim. Thus, the first incidence of violence as recorded in Genesis 4 can be of great help to describe what terrorism is today and how the Christians in Nigeria can respond it.

Violence is a violent action by perpetrators against victims. It is an intentional killing or shedding of the blood of victims (Gen 4:8). Mark Douglas defines it as 'a forceful action that intends to cause unwanted injury, to another'. It may even cause death, psychological harm, and destruction of property. ${ }^{10}$ Both the perpetrators and the victims are God's creations (Gen 4). Victims are always helpless, defenseless, weak, righteous or innocent (Gen 4:4). Violence may occur between two different persons or groups of people. It may be as differences in religious or ethnic groups (Gen 4:1-2).

There are various causes of terrorism, which is a form of violence. These causes may be because of an inferiority complex, resentment, bitterness, jealousy and envy (Gen 4:5-7). Perpetrators are always under the influence of $\sin$ and the devil (Gen 4:7). They have been mastered by sin and are under the control of the devil. It is worthy to note that terrorism is a sin against God. God frowns at it. He always wishes that it did not take place (Gen 4:6-7). Sometimes, he allows righteous to be victims. Anytime, righteous are victims, God investigates such violent actions against them (Gen 4:9). Afterward, he prosecutes the perpetrators in his own way (Gen 4:1112). Before him, the perpetrators are considered blood guilty, and they are liable to punishment. They cannot escape God's judgment because it is very sure. As it may be expected, the judgment may not be immediate death. Perpetrators may be banned from enjoying God's presence and blessings (Gen 4:12). Therefore, they become wanderer and fugitive, they live in the forest, a place where one cannot find humans. Such punishment is even

\footnotetext{
${ }^{1}$ Hamilton, 230.

${ }^{2}$ Rad, Genesis: A Commentary, 106.

${ }^{3}$ Hamilton, The Book of Genesis Chapters 1-17, 231.

${ }^{4}$ Rad, Genesis: A Commentary, 106.

${ }^{5}$ Hamilton, The Book of Genesis Chapters 1-17, 232.

${ }^{6} \mathrm{Rad}$, Genesis: A Commentary, 106.

${ }^{7}$ Hamilton, The Book of Genesis Chapters 1-17, 233.

${ }^{8}$ Hamilton, 234-235.

9 E.A. Speiser, Genesis: Introduction, Translation, and Notes, (The Anchor Bible) (New York: Doubleday and Company, Inc., 1964), 31.

${ }^{10}$ Mark Douglas, "Violence," Dictionary of Scripture and Ethics, edited by Joel B. Green (Grand Rapids: Baker Pub. Group, 2011), 809-810.
} 
greater than death. God is absent from the generations of the perpetrators. Most often, their descendants always perpetuate terrorism (Gen 4:23). Thus, terrorism will continue to be present in the earth.

There are various forms of terrorism against Christians in Nigeria. There are many extremists' attacks against Christians in Nigeria. In the night, these extremists would just enter Christians' places of abode, kill many and burn down their houses. During the day, the armed people would just be shooting the innocent and helpless Christians. Despite all these killings and burnings of houses, there is no justice for them from the Nigerian government can do. These extremists would not be arrested, and they would continue to live in the streets of the nation.

\subsection{The Response of Christians in Nigeria to Terrorism}

Christians in Nigeria can respond to violent actions against them in various ways. One way is through retaliation. This means that they will also have to be violent or perpetrate violent actions against their enemies. They can shed blood and cause harm to others. They can even destroy properties. The implication of this is that they are also under the control of sin and the devil. This will make them sin against God, and God's judgment will likewise be brought on them. For this reason, Ogunlana emphasizes that:

Christians should desist from harming others because they will have to face God's wrath. In addition, whenever Christians are harmed, they should not avenge themselves, rather they should leave vengeance to the Lord. They should 'repay no one evil for evil' (Rom 12:17). They should not take personal revenge. They should not live by the rule of revenge. They should learn to have faith in Jesus Christ who will avenge them of the evil done to them. ${ }^{1}$

This, then, demonstrates that the response through retaliation is not an appropriate one. The appropriate response of Christians in Nigeria to terrorism should be love and forgiveness for enemies, and dialogue and reconciliation with enemies. However, the response that will be elaborated in this article is a response through prayer. In Genesis 4:10, the voice of Abel's blood cried to Yahweh from the ground, and Yahweh heard his voice. Consequently, Yahweh arose to take vengeance against Cain.

For the Christians in Nigeria, this should be an appropriate response to terrorism. Since, Christians are helpless, weak, innocent and defenseless in the face of violence; they should learn to cry to Yahweh who is allpowerful to avenge them of the violent actions against them. God is ready to arise for their help and defense. Jesus Christ, who is the center of existence and the final arbiter of justice, will repay any harm done to Christians. Little wonder, Paul mentions to the Roman Christians that vengeance is the Lord's, and he will repay every harm done to Christians (Rom 12:19, cf. Deut 32:35). ${ }^{2}$

For God to avenge Christians in Nigeria of the violent actions against them, they must pray to God. Prayer is, therefore, the cry of helpless and defenseless Christians to God. It is the cry of the oppressed, the afflicted, the stranger, the weak, and the helpless. It is considered the groans of innocent victims who are violated. It is a communication between God and Christians. It is the cry of Christians to God for help and defense. It is the cry of Christians to God for protection from every form of violent action. It is the cry of Christians to God to caution the perpetrators from their acts of perpetrating violent actions. It is the cry of Christians to God to destroy the power of the devil and sin in the lives of the perpetrators of violence. It is the cry of Christians to God to investigate into every violent action melted against them. It is the cry of Christians to God to vindicate them for every violent that has been done against them. It is the cry of Christians to God to bring judgment on the perpetrators of terrorism in his own way. It is the cry of Christians to God to have mercy on the perpetrators of terrorism and to show them the way, the truth, and the life so that they would not perish. When Christians cry to God like Abel's blood, they are leaving the matter into the hand of God, and God will definitely respond to them appropriately in his own way.

\section{Conclusion}

If Christians cry to God in prayer because of terrorism against them, God will caution the perpetrators of terrorism, he will destroy the power of sin and the devil behind violence, he will avenge the blood of the innocent people shed, he will bring judgment on the perpetrators, and he may have mercy and save some of them.

\section{References}

Collins, C. John. Genesis 1-4: A Linguistic, Literary, and Theological Commentary. Phillipsburg: P\&R Publishing, 2006.

Douglas, Mark. "Violence." Dictionary of Scripture and Ethics. Edited by Joel B. Green. Grand Rapids: Baker Pub. Group, 2011.

Hamilton, Victor P. The Book of Genesis Chapters 1-17. (The International Commentary on the Old Testament).

\footnotetext{
${ }^{1}$ Babatunde Adekunle Ogunlana, "Lex Talion in Exodus 21:22-25: Its Context, Interpretation, and Application for Christian Living", A Paper Presented at Kagoro Journal of Theology (KAJOT) International Conference, (Kagoro: ECWA Theological Seminary, 2016), 11-12.

${ }^{2}$ Ogunlana, 11
} 
Grand Rapids: Eerdmans, 1990

Ogunlana, Babatunde Adekunle. "Lex Talion in Exodus 21:22-25: Its Context, Interpretation, and Application for Christian Living." A Paper Presented at Kagoro Journal of Theology (KAJOT) International Conference. Kagoro: ECWA Theological Seminary, 2016.

Rad, Gerhard von. Genesis: A Commentary. (The Old Testament Library). Philadelphia: The Westminster Press, 1972.

Speiser, E.A. Genesis: Introduction, Translation, and Notes. (The Anchor Bible). New York: Doubleday and Company, Inc., 1964. 